\title{
High Expression of microRNA-371a-3p in Cystic Fluid of Post-Chemotherapy Teratoma with Concurrent Normal Serum Levels in Patients with Non-Seminomatous Testicular Germ Cell Tumours
}

\author{
Klaus-Peter Dieckmann ${ }^{\mathrm{a}, \mathrm{b}}$ Finja Hennig ${ }^{c}$ Petra Anheuser ${ }^{\mathrm{b}}$ Ralf Gehrckens ${ }^{d}$ \\ Florian Viehweger $^{\mathrm{e}}$ Christian Wülfing ${ }^{\mathrm{a}}$ Gazanfer Belge ${ }^{c}$

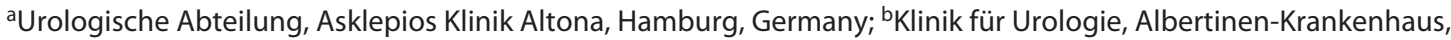 \\ Hamburg, Germany; ${ }^{C}$ Fachbereich Biologie, Universität Bremen, Bremen, Germany; ${ }^{d}$ Abteilung Diagnostische

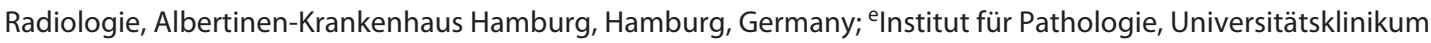 \\ Eppendorf, Hamburg, Germany
}

\section{Keywords}

Testicular germ cell tumour - Biomarker .

MicroRNA-371a-3p - Teratoma - Cystic fluid .

Retroperitoneal lymph node dissection

\begin{abstract}
Background: MicroRNA-371a-3p (miR-371), the novel serum biomarker of testicular germ cell tumours (GCTs), is produced by undifferentiated subtypes of GCTs but not by teratoma. Cystic teratoma developing from retroperitoneal metastases of GCT subsequent to chemotherapy had been shown to contain high levels of classical serum tumour markers of GCT in the presence of normal marker levels in serum. To date, no information is available regarding the presence of miR-371 in the cystic fluid of residual teratoma after chemotherapy. Methods: Four patients (age 18-26 years) undergoing retroperitoneal lymph node dissection (RPLND) for cystic residual masses resulting from chemotherapy of bulky retroperitoneal GCT had measurements of miR-371 in both serum and cystic fluid aspirated from surgical specimens. Measurement of the miR was performed with quantitative real-time PCR using miR-30b-5p as reference. Results were tabulated and analysed in a descriptive manner. Results: Histologically, all of the surgical specimens involved teratoma
\end{abstract}

karger@karger.com

(c) 2020 S. Karger AG, Basel

www.karger.com/uin

Karger! only with no evidence of vital undifferentiated GCT tissue. All patients were cured. Prior to RPLND, miR-371 serum levels were not measurable or close to zero in all of the patients. Cystic fluid revealed elevated levels of miR-371 in 3 patients and traces of miR in one. Conclusions: The detection of miR371 in the cystic fluid of teratoma is somewhat enigmatic since this GCT subtype usually does not express the miR. Two hypotheses may explain the finding: First, miR-371 molecules were released into the cystic fluid by active GCT tissue prior to chemotherapy. High levels were kept after regression of vital GCT tissue because the cystic lumen is without a specific drainage system. Second, teratoma cells lining the interior cyst wall may shed small amounts of miR-371 into the lumen. Because of the lacking drainage system, even small levels may accumulate. The present finding adds to the understanding of the biology of the novel biomarker of GCT.

(c) 2020 S. Karger AG, Basel

\section{Introduction}

An ideal serum tumour marker is thought to comprise a number of distinctive features: firstly, the production of the marker substance solely by tumour cells; secondly, the excretion of the substance into body fluids where it is eas- 
Table 1. Patient characteristics

\begin{tabular}{|c|c|c|c|c|c|c|c|}
\hline No. & $\begin{array}{l}\text { Age, } \\
\text { years }\end{array}$ & Primary tumour histology & $\begin{array}{l}\text { Clinical } \\
\text { stage } \\
\text { (Lugano) }\end{array}$ & IGCCCG & $\begin{array}{l}\text { Chemo- } \\
\text { therapy }\end{array}$ & $\begin{array}{l}\text { Size of cyst } \\
\text { in residual } \\
\text { tumour, mm }\end{array}$ & Residual tumour histology \\
\hline 1 & 18 & $80 \%$ teratoma, $15 \%$ embryonal ca, $5 \%$ yolk sac tumour & 3 & Intermediate & 4XBEP & 75 & Teratoma, no vital cancer \\
\hline 2 & 26 & Burnt-out tumour, GCNis & 3 & Poor & 4xPEI & 62 & Teratoma, no vital cancer \\
\hline 3 & 25 & $100 \%$ embryonal ca & $2 b$ & Good & $3 \times B E P$ & 30 & Teratoma, no vital cancer \\
\hline 4 & 22 & Teratoma, GCNis & $2 c$ & Good & $3 x B E P$ & 98 & Teratoma, no vital cancer \\
\hline
\end{tabular}

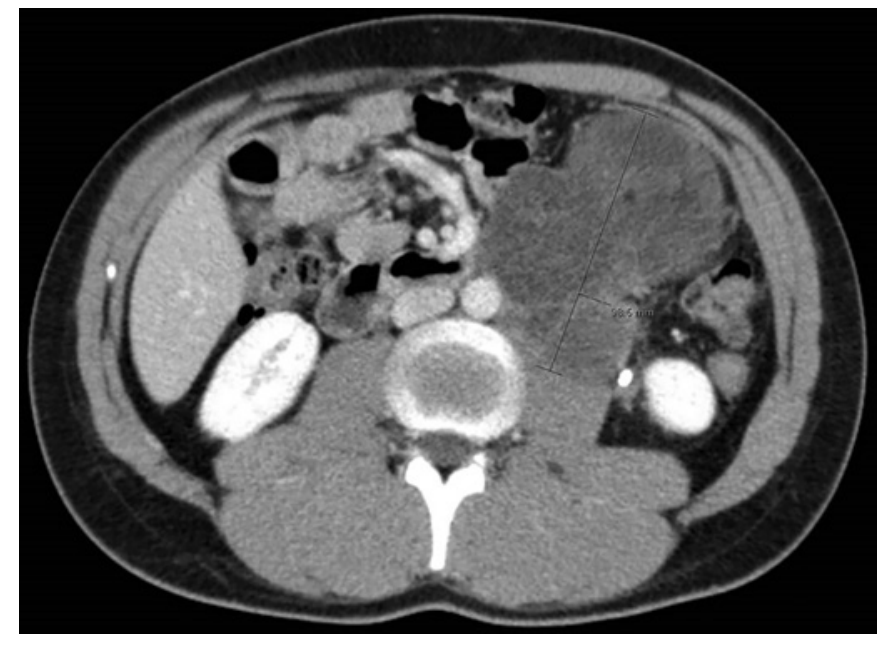

Fig. 1. Computed tomography of abdomen, axial scan, showing a cystic structure reaching from the abdominal aorta to the anterior abdominal wall. Note the double-J stent in the left ureter (patient \#4). Fluid was aspirated from this cyst for analysis of miR-371.

ily measurable; and thirdly and importantly, a close correlation of the serum marker levels with tumour burden and, thus, with response to treatment [1]. The classical serum biomarkers of testicular germ cell tumours (GCTs), alpha fetoprotein (AFP), the beta subunit of human chorionic gonadotropin (bHCG), and lactate dehydrogenase, have been demonstrated to fulfil several but not all of these criteria. The clinical utility of the classical markers is mainly hampered not only by their low sensitivity of around $40-50 \%$ but also by their lack of specificity, as these substances may also be produced by non-GCT-related diseases [2-4].

Cystic teratoma is a typical finding in GCT patients undergoing post-chemotherapy retroperitoneal lymph node dissection (pcRPLND) of residual tumours after chemotherapy for bulky retroperitoneal tumour masses.
The fluid aspirated from these cystic residual masses was shown to contain high amounts of the classical tumour markers AFP and bHCG, while concurrently low or normal levels of these markers were found in serum [5-8]. A clear biological mechanism to explain the discordant findings in the 2 compartments is yet to be found.

Recently, serum levels of microRNA-371a-3p (miR371) have evolved as a promising new serum biomarker of GCT with very high sensitivities and specificities of $>90 \%[9,10]$. This miR is specifically produced by human embryonic stem cells, and because of the close biological relationship of embryonic stem cells with human germ cells, miR-371 is also found in high amounts in undifferentiated germ cell tumours and in still low amounts in normal testicular germ cells $[11,12]$. Notably, it is not detected or only detected in very little amounts in welldifferentiated teratoma [13-16]. Serum levels of miR-371 correlate well with disease burden and with treatment [17]. Apart from serum, it has been detected in various body fluids [18], but to date, there is no information about the presence of the new GCT marker in the cystic fluid of residual teratomas subsequent to chemotherapy. We hypothesized that - in analogy to GCTs - miR-371 would be detectable in cystic fluid even when no expression of the $\mathrm{miR}$ is found in serum. Here, we report the first experience with measurement of miR-371 in teratomatous cystic fluid.

\section{Materials and Methods}

Patients

The clinical characteristics of the 4 patients included in this study are summarized in Table 1. Briefly, all of the patients presented with metastasized non-seminomatous testicular GCTs and elevated levels of classical tumour markers. Cisplatin-based chemotherapy caused regression of metastatic deposits and normalization of tumour markers. Radiologically, all residual masses involved cystic compartments along with solid masses (Fig. 1). All of the patients underwent open pcRPLND with complete resection of
Urol Int 2021;105:21-26 DOI: $10.1159 / 000510760$
Dieckmann/Hennig/Anheuser/ Gehrckens/Viehweger/Wülfing/Belge 
Table 2. Tumour markers in serum and cysts

\begin{tabular}{|c|c|c|c|c|c|c|c|c|c|c|c|c|}
\hline Patient No. & $\begin{array}{l}\text { AFP, } \\
\mathrm{ng} / \mathrm{mL}\end{array}$ & $\begin{array}{l}\text { bHCG, } \\
\text { U/L }\end{array}$ & $\begin{array}{l}\mathrm{LDH}, \\
\mathrm{U} / \mathrm{L}\end{array}$ & $\begin{array}{l}\text { miR-371 } \\
\text { (RQ) }\end{array}$ & $\begin{array}{l}\text { AFP, } \\
n g / m L\end{array}$ & $\begin{array}{l}\text { bHCG, } \\
\text { U/L }\end{array}$ & $\begin{array}{l}\mathrm{LDH}, \\
\mathrm{U} / \mathrm{L}\end{array}$ & $\begin{array}{l}\text { miR-371 } \\
\text { (RQ) }\end{array}$ & $\begin{array}{l}\text { AFP, } \\
\text { ng/mL }\end{array}$ & $\begin{array}{l}\text { bHCG, } \\
\text { U/L }\end{array}$ & $\begin{array}{l}\mathrm{LDH}, \\
\mathrm{U} / \mathrm{L}\end{array}$ & $\begin{array}{l}\text { miR-371 } \\
\text { (RQ) }\end{array}$ \\
\hline 1 & 4.178 & 70.6 & 267 & 352.45 & 3.86 & 0.78 & 235 & 0 & 2.63 & 16.16 & 48 & 1.74 \\
\hline 2 & 1.1 & 192.670 & 520 & n.a & 1.6 & 16.8 & 170 & 0 & n.a & n.a & n.a & $5,601.79$ \\
\hline 3 & 2.5 & 32.0 & n.a & n.a & 2.5 & 1.2 & 166 & 0 & n.a & n.a & n.a & 37.19 \\
\hline
\end{tabular}

n.a, not available; RQ, relative quantity.

the residual masses and subsequent histologic workup of specimens. Serum levels of the classical tumour markers and of miR-371 were recorded at first diagnosis and at the time of pcRPLND. Cystic fluid was aspirated from the surgical specimens and kept deepfrozen until laboratory processing with measurement of miR-371. All patients had given informed consent. Ethical approval was provided by Ärztekammer Bremen (reference no. 301, 2011). All study activities had been conducted according to the Declaration of Helsinki of the World Medical Association (as amended by the 64th General Assembly, 2013).

\section{Laboratory Technique}

Measurement of serum levels of the classical tumour markers was performed in hospital laboratories according to institutional technical guidelines, with employment of commercially available laboratory kits. Measurement of miR-371 levels in serum and in cystic fluid was performed as reported earlier [13]. Briefly, total RNA was isolated from $200 \mu \mathrm{L}$ of both serum and cystic fluid using the miRNeasy Mini Kit according to the manufacturer's instructions. After reverse transcription with the TaqMan MicroRNA Reverse Transcription Kit, the cDNA was preamplified, and levels of miR-371a-3p (assay ID: 000564) and the reference miR-30b-5p (assay ID: 000602) were measured by quantitative PCR using the Applied Biosystems 7500 Real-Time PCR System. The relative quantity of miR-371a-3p was calculated according to the $\Delta \Delta C T$ method [19].

\section{Results}

At diagnosis, all patients had elevated levels of at least one of the classical markers. Measurement of serum levels of miR-371 at the time of first diagnosis was only available in 1 patient (\#1) because the other patients had received their primary treatment at other institutions. At the time of RPLND, marker levels had normalized (Table 2) except for patient \#2. This patient had a serum bHCG level still slightly above the upper limit of normal, but it had been continuously decreasing during the course of treatment. In view of the excessively increased level of bHCG at the outset, this level was considered to correspond to the half-

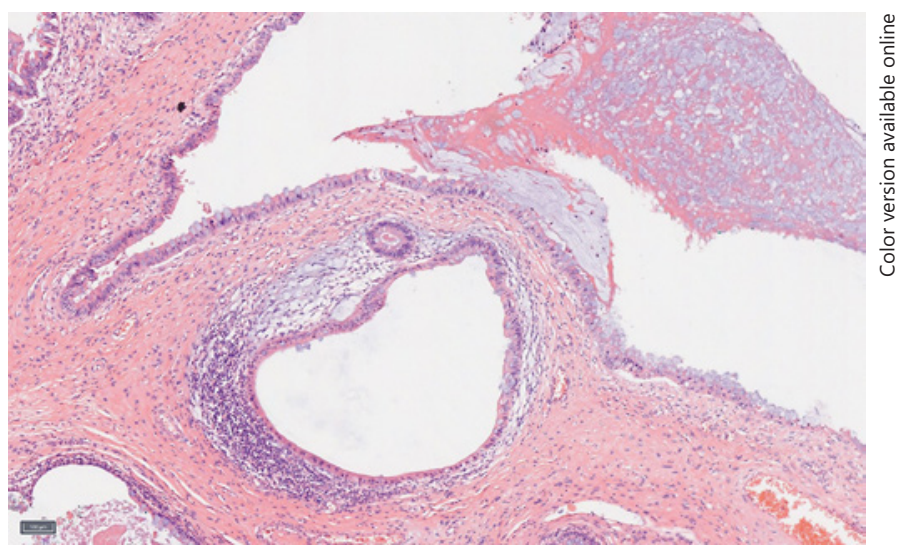

Fig. 2. Histological section of surgical specimen of patient \#4: mucin-filled cystically configured retroperitoneal lesion with a lining of predominantly intestinal epithelium matching further teratoma parts. Adjacent stroma with fibrosis, and chronic lymphocytic and focal foamy histiocytic inflammation. Typical cystic teratoma; no vital germ cell cancer. Haematoxylin-eosin stain, original $\times 100$.

life of bHCG. Serum levels of miR-371 were virtually not measurable prior to RPLND in 3 patients, while the fourth patient had a serum level close to zero (relative quantity 0.08 ). Histologically, all 4 surgical specimens consisted of mature teratoma along with necrotic tissue but without any vital cancer (Fig. 2). Three of the samples of the aspirated cystic fluid revealed unequivocally elevated levels of miR-371 (cases \#2-4, Table 2), while in case \#1 there were only traces of miR-371 detectable in the cystic fluid. In case \#1, the cystic fluid also showed a slight elevation of bHCG in the presence of a normal serum level. In the other cases, cystic fluid was not available for measurement of classical markers. 


\section{Discussion}

The central result of the present study is the finding of elevated miR-371 levels in the cystic fluid of teratomacontaining residual masses evolving from chemotherapy of bulky metastases of GCTs in the presence of normal levels of miR in serum. This finding is consistent with the discrepant results found in pair-wise measurements of classical markers in cystic fluid and serum, respectively, as reported previously [5-8]. As shown by Ockhuizen et al. [5], teratomatous cystic fluid is widely similar to serum in regard to the protein composition [5]. The documentation of an increased expression of miR-371 in the cystic fluid of teratomas is somewhat enigmatic because teratoma usually lacks the expression of this $\operatorname{miR}[10,14]$. It is therefore rational to hypothesize that the high $\mathrm{miR} \mathrm{lev-}$ els in the cystic fluid stem from the secretion of an miRsubstance by vital undifferentiated GCTs originally neighbouring the cyst lumen. The same mechanism is thought to cause the increased miR-371 levels in the tumour-surrounding hydrocele fluid [20].The contents of the cyst represent a sealed compartment with no structured communication to other body compartments except for the physical process of diffusion. However, diffusion processes are probably kept at a minimum because of the thick fibrotic wall of most of the cysts. Therefore, most of the substance once secreted into the cyst lumen will remain unchanged in the cyst even after regression of the miRNA-producing neoplastic tissue secondary to chemotherapy. In line with this hypothesis is the observation of minimally increased serum levels of the classical markers despite complete regression of neoplastic tissue as observed in case $\# 2$ of this series and which is thought to represent a leakage from non-vital compartments with persisting elevated tumour marker concentrations $[8$, 21].

However, excretion of the miR-substance into the cyst lumen by teratomatous elements cannot entirely be ruled out. Teratoma usually does not express miR-371 because this histologic subtype of GCT is morphologically welldifferentiated and, thus, clearly devoid of miR-producing stem-cell-like properties. However, a weak expression of the miR has been demonstrated in isolated cases [13], and accordingly, van Agthoven and Looijenga [14] documented slightly but significantly higher miR-371 serum levels in patients with testicular teratoma than in healthy blood donors. Also, Vilela-Salgueiro et al. [22] found trace amounts of the miR in the tissue of adult testicular teratomas. It is thus still conceivable that teratomatous elements lining the interior cyst wall express the miR and continuously shed small amounts into the cyst lumen. As there is no structured drainage system to the cyst, even small amounts of the miR may accumulate and then reach measurable levels.

Our observation of discrepant expressions of miR-371 in serum and in cystic fluid of residual masses after chemotherapy probably does not have a bearing on clinical decision-making since all of the patients reported herein remained disease-free after RPLND. This conclusion is at odds with the hypothesis of Hölzel et al. [7] who postulated inferior survival in those patients with elevated AFP in teratomatous cystic fluid at RPLND. Yet, our finding is interesting biologically because the phenomenon of discrepant levels in serum and cystic fluid, respectively, was likewise found with AFP and bHCG. Thus, discordant expression in various body fluids appears to be a typical feature of biomarkers of GCT, and miR-371 does clearly exhibit this feature.

It remains unresolved if the miR-371 level detected in the cystic fluid is associated with particular clinical features. Noteworthy, case \#2 had extremely high serum levels of bHCG at diagnosis corresponding to the IGCCCG poor prognosis group, and he was found to have the highest level of the miR in the cystic fluid. Our finding is somehow at variance with the classical markers because miR-371 was unequivocally detected in only 3 of the cysts, while in the fourth only traces were identified. By contrast, bHCG or AFP had been found in all of the teratomatous cystic fluids reported so far [5-8]. Whether or not the extremely short half-life of miR-371 may have contributed to this finding remains conjectural [23].

After the discovery of circulating miR-371 in the serum of GCT patients, the miR has been detected in a variety of other body fluids, such as plasma, testicular vein blood, tumour-surrounding hydrocele fluid, cerebrospinal fluid of patients with intracranial GCT, pleural effusion, seminal plasma, and ejaculate fluid, but not in urine $[18,20,24-27]$. The documentation of miR-371 in the fluid of teratomatous cysts adds, therefore, one further body fluid to the list of compartments where expression of the miR is found, thus enhancing our understanding of the biology of both miR-371 and GCT.

Our study results are certainly limited by the small number of patients involved, by lacking miR-371 measurements at the time of diagnosis in 3 patients, and by the fact that only in 1 case classical markers were measured in cystic fluid. However, cystic residual masses after chemotherapy of GCT are far from common. Therefore, even well-selected small patient samples may involve
Dieckmann/Hennig/Anheuser/ Gehrckens/Viehweger/Wülfing/Belge 
valuable information. Accordingly, the results reported herein are both clear-cut and novel, and thus warrant documentation.

\section{Acknowledgements}

The authors are grateful to laboratory staff members of Albertinen-Krankenhaus, Hamburg, and Asklepios Klinik Altona, Hamburg, for carefully handling and securing serum and cystic fluid samples. Dr. Raphael Ikogho assisted in ascertaining of clinical data.

\section{Statement of Ethics}

All patients had given informed consent. Ethical approval was provided by Ärztekammer Bremen (reference no. 301, 2011). All study activities had been conducted according to the Declaration of Helsinki of the World Medical Association (as amended by the sixty-fourth General Assembly, 2013).

\section{Conflict of Interest Statement}

K.P.D. and G.B. both possess ownership shares of $9.7 \%$ of miRdetect $\mathrm{GmbH}$, Bremen, a start-up company aiming to produce a commercially available laboratory kit for measurement of microRNAs in serum. All other authors declare no conflicts of interest.

\section{Funding Sources}

This study received support from the Wilhelm Sander Stiftung, München (No. 2014.178.2). The funding institution had no influence in preparation of the data and the manuscript.

\section{Author Contributions}

Study concept: K.P.D. and P.A. Ascertainment of clinical data: C.W., F.V., P.A., and R.G. MicroRNA measurement: G.B. and F.H. Interpretation of data: K.P.D. and G.B. Manuscript writing: K.P.D., G.B., and P.A. All authors critically reviewed and finally approved the manuscript.

\section{References}

1 Lange PH, Winfield HN. Biological markers in urologic cancer. Cancer. 1987;60(3 Suppl): $464-72$.

2 Leão R, Ahmad AE, Hamilton RJ. Testicular cancer biomarkers: a role for precision medicine in testicular cancer. Clin Genitourin Cancer. 2018;17:e176-83.

3 Murray MJ, Huddart RA, Coleman N. The present and future of serum diagnostic tests for testicular germ cell tumours. Nat Rev Urol. 2016;13(12):715-25.

4 Dieckmann KP, Simonsen-Richter H, Kulejewski $\mathrm{M}$, Anheuser $\mathrm{P}$, Zecha $\mathrm{H}$, Isbarn $\mathrm{H}$, et al. Serum tumour markers in testicular germ cell tumours: frequencies of elevated levels and extents of marker elevation are significantly associated with clinical parameters and with response to treatment. Biomed Res Int. 2019;2019:5030349

5 Ockhuizen T, Veenstra J, Suurmeijer AJ, Fleuren GJ, Schraffordt Koops H, de Bruijn $\mathrm{HW}$, et al. Protein composition of cyst fluids from mature teratoma in patients with nonseminomatous germ cell tumors of the testis. Cancer. 1985;56(9):2264-8.

6 Sella A, el Naggar A, Ro JY, Dexeus FH, Amato RJ, Lee JS, et al. Evidence of malignant features in histologically mature teratoma. Urol. 1991;146(4):1025-8.

7 Hölzel C, Weissbach L, Mann K. Prognostische Bedeutung von Tumormarkern in Zystenpunktaten fortgeschrittener Keimzelltumoren nach Chemotherapie. Aktuel Urol. 1997;28(5):260-2.
8 Beck SD, Patel MI, Sheinfeld J. Tumor marker levels in post-chemotherapy cystic masses: clinical implications for patients with germ cell tumors. J Urol. 2004;171(1):168-71.

9 Almstrup K, Lobo J, Mørup N, Belge G, Rajpert-De Meyts E, Looijenga LHJ, et al. Application of miRNAs in the diagnosis and monitoring of testicular germ cell tumours. Nat Rev Urol. 2020;17(4):201-13.

10 Regouc M, Belge G, Lorch A, Dieckmann $\mathrm{K}-\mathrm{P}$, Pichler M. Non-coding microRNAs as novel potential tumor markers in testicular cancer. Cancers. 2020;12(3):749.

11 Belge G, Hennig F, Dumlupinar C, Grobelny F, Junker K, Radtke A, et al. Graded expression of microRNA-371a-3p in tumor tissues, contralateral testes, and in serum of patients with testicular germ cell tumor. Oncotarget. 2020;11(16):1462-73.

12 Lobo J, Gillis AJM, Jerónimo C, Henrique R, Looijenga LHJ. Human germ cell tumors are developmental cancers: impact of epigenetics on pathobiology and clinic. Int J Mol Sci. 2019;20(2):258

13 Dieckmann KP, Radtke A, Geczi L, Matthies C, Anheuser P, Eckardt U, et al. Serum levels of microRNA-371a-3p (M371 test) as a new biomarker of testicular germ cell-tumors: results of a prospective multicentric study. J Clin Oncol. 2019;37:1412-23. 10.1200/ JCO.18.01480.

14 van Agthoven T, Looijenga LHJ. Accurate primary germ cell cancer diagnosis using serum based microRNA detection (ampTSmiR test). Oncotarget. 2017;8(35):58037-49.
15 Lobo J, Gillis AJM, van den Berg A, Dorssers LCJ, Belge G, Dieckmann K-P, et al. Identification and validation model for informative liquid biopsy-based microRNA biomarkers: insights from germ cell tumor in vitro, in vivo and patient-derived data. Cells. 2019;8(12): 1637.

16 Leão R, van Agthoven T, Figueiredo A, Jewett MAS, Fadaak K, Sweet J, et al. Serum miRNA predicts viable disease after chemotherapy in patients with testicular nonseminoma germ cell tumor. J Urol. 2018. 200(1):126-35.

17 Rosas Plaza X, van Agthoven T, Meijer C, van Vugt MATM, de Jong S, Gietema JA, et al. miR-371a-3p, miR-373-3p and miR-367-3p as serum biomarkers in metastatic testicular germ cell cancers before, during and after chemotherapy. Cells. 2019;8(10):1221.

18 Spiekermann M, Belge G, Winter N, Ikogho R, Balks T, Bullerdiek J, et al. MicroRNA miR$371 a-3 p$ in serum of patients with germ cell tumours: evaluations for establishing a serum biomarker. Andrology. 2015;3(1):78-84.

19 Livak KJ, Schmittgen TD. Analysis of relative gene expression data using real-time quantitative PCR and the 2(-Delta Delta C(T)) method. Methods. 2001;25(4):402-8.

20 Dieckmann KP, Spiekermann M, Balks T, Ikogho R, Anheuser P, Wosniok W, et al. MicroRNA miR-371a-3p: a novel serum biomarker of testicular germ cell tumors: evidence for specificity from measurements in testicular vein blood and in neoplastic hydrocele fluid. Urol int. 2016;97:76-83. 
21 Ong TA, Winkler MH, Savage PM, Seckl MJ, Christmas TJ. Retroperitoneal lymph node dissection after chemotherapy in patients with elevated tumour markers: indications, histopathology and outcome. BJU Int. 2008; 102(2):198-202.

22 Vilela-Salgueiro B, Barros-Silva D, Lobo J, Costa AL, Guimarães R, Cantante $\mathrm{M}$, et al. Germ cell tumour subtypes display differential expression of microRNA371a-3p. Philos Trans R Soc Lond B Biol Sci. 2018;373(1748): 20170338.
23 Radtke A, Hennig F, Ikogho R, Hammel J, Anheuser P, Wülfing C, et al. The novel biomarker of germ cell tumours, microRNA-371a-3p, has a very rapid decay in patients with clinical stage 1 . Urol Int. 2018; 100(4):470-5.

24 Mego M, van Agthoven T, Gronesova P, Chovanec M, Miskovska V, Mardiak J, et al. Clinical utility of plasma miR-371a-3p in germ cell tumors. J Cell Mol Med. 2019;23(2):1128-36.

25 Boellaard WPA, Gillis AJM, van Leenders GJLH, Stoop H, van Agthoven T, Dorssers LCJ, et al. Cellular origin of microRNA-371a$3 p$ in healthy males based on systematic urogenital tract tissue evaluation. Andrology. 2019;7(4):463-8.
26 Murray MJ, Bell E, Raby KL, Rijlaarsdam MA, Gillis AJ, Looijenga $\mathrm{LH}$, et al. A pipeline to quantify serum and cerebrospinal fluid microRNAs for diagnosis and detection of relapse in paediatric malignant germ-cell tumours. Br J Cancer. 2015;114(2):151-62.

27 Nappi L, Thi M, Lum A, Huntsman D, Eigl BJ, Martin C, et al. Developing a highly specific biomarker for germ cell malignancies: plasma miR371 expression across the germ cell malignancy spectrum. J Clin Oncol. 2019;37(33): 3090-8. 